\title{
The Effects of Aluminum and Nitrogen on the Creep Rupture Strength of Low Alloy Cr-Mo Steels*
}

\author{
By Teruo YUKITOSHI** and Kazuhiko NISHID $A^{* *}$
}

\begin{abstract}
Synopsis
The effects of aluminum and nitrogen on the creep rupture strength of low alloy $\mathrm{Cr}-\mathrm{Mo}$ steels have been studied. Results obtained are as follows:

(1) A small amount of aluminum addition causes a detrimental effect on creep rupture strength.

(2) The effect of ferrite grain size is studied by varying austenitizing temperature; specimens with coarse grain show a better creep resistance than those with fine grain size.

(3) Residue analyses clarify that the amount of nitrogen as nitride in as heat treated specimens shows an increasing tendency with increasing chromium content. In the case of $1 \mathrm{Cr}-1 / 2 \mathrm{Mo}$ steel, all of the nitrogen in the steel exists as $\mathrm{CrN}$. This means that the detrimental effect of aluminum addition can not be ascribed to the decrease in the amount of active nitrogen.

(4) Grain refining effect of AIN is suggested to play an important role on the detrimental effect of aluminum addition.

From these results, the detrimental effect of aluminum on creep strength was suggested to be ascribed to the grain size dependency, including not only a direct geometrical shape of grains but also suspected morphological changes of precipitates due to grain size.
\end{abstract}

\section{Introduction}

The effects of aluminum and nitrogen on the creep strength of carbon steel have been studied by many investigators and can be said to have been clarified. ${ }^{1-3)}$ Low alloy steels are used instead of carbon steels at higher temperatures; low alloy steels contain strong carbide forming elements such as chromium or molybdenum so as to get enough creep strength. These carbide forming elements make it difficult to analyze the result and to get a simple factor, such as the role of active nitrogen in carbon steel.

Published reports showed that a small amount of aluminum addition gave a detrimental effect on creep strength; Terai ${ }^{4-6)}$ measured the creep rate of fully annealed $1 \mathrm{Cr}-1 / 2 \mathrm{Mo}$ steel and observed that aluminum addition accelerated the creep rate of the steel. The decrease in creep rate was also observed to depend on austenitizing temperature. This dependency was ascribed to the variation of the amount of active nitrogen. Yūki ${ }^{7)}$ also studied the effect of aluminum on the fully annealed $21 / 4 \mathrm{Cr}-1 \mathrm{Mo}$ and $5 \mathrm{Cr}-1 / 2 \mathrm{Mo}$ steels. Both steels were shown to decrease their rupture time with increasing the amount of aluminum up to $0.048 \%$. This was assumed to be the effect of stabilization of nitrogen by aluminum. Mimino et al. ${ }^{8)}$ measured the creep rupture strength of $1 / 2 \mathrm{Mo}, 1 \mathrm{Cr}-1 / 2 \mathrm{Mo}$, $1 \mathrm{l} / 4 \mathrm{Cr}-1 \mathrm{Mo}$, and $2 \mathrm{1} / 4 \mathrm{Cr}-1 \mathrm{Mo}$ steels with various aluminum and nitrogen contents. A slight decrease in creep rupture strength was observed in high nitrogen and aluminum steel and this was supposed to be ascribed to the easier coagulation of carbides in the steel.

As summarized above, all of the published reports coincided in the point that the addition of aluminum has a detrimental effect on creep strength. But it remains unsolved whether the result can be explained by active nitrogen, which has a great effect on the creep strength of carbon steel. Even if there is active nitrogen in the steel, it is not certain whether the active nitrogen can work effectively at such high temperatures as $550^{\circ} \mathrm{C}$. Besides, there is some possibility that aluminum addition may change the morphology of carbides and it is also well known that grain size refinement can be achieved by the addition of aluminum in steel. In the above reports, austenite grain size was used, but ferrite grain size may be preferable.

As mentioned above, the effects of aluminum and nitrogen on the creep strength of low alloy steels still remain somewhat obscure. The purpose of this report is to examine the effects of aluminum and nitrogen on creep strength and try to clarify the reason for them.

\section{Experimental Procedure}

Materials studied were $1 \mathrm{Cr}-1 / 2 \mathrm{Mo}$ steels containing $0.002-0.011 \% \mathrm{~N}$ and $0-0.02 \% \mathrm{Al}$. Chemical compositions are shown in Table 1 . Steel $D$ was vacuummelted, and the all the other steels were air-melted. Among them, steel $E$ was specially used for studying the effect of grain size on creep strength and steels $F$ and $G, 21 / 4 \mathrm{Cr}-1$ Mo steels, were used for clarifying the effect of tempering on creep strength. Considering the precipitation behaviour of AIN, two heat treatments were selected. Heat treatment $A: 920^{\circ} \mathrm{C}$ $\times 30 \mathrm{~min} \rightarrow 720^{\circ} \mathrm{C} \times 25 \mathrm{~min}$ A.C. Heat treatment $B$ : $920^{\circ} \mathrm{C} \times 30 \mathrm{~min}$ A.C. $+720^{\circ} \mathrm{C} \times 25 \mathrm{~min}$ A.C. After heat treatment, specimens for creep rupture test were

Table 1. Chemical composition of steels studied

\begin{tabular}{|c|c|c|c|c|c|c|c|}
\hline Mark & $\mathrm{C}$ & $\mathrm{Si}$ & $\mathrm{Mn}$ & $\mathrm{Cr}$ & Mo & $\mathrm{N}$ & Sol. Al \\
\hline$A$ & 0.13 & 0.30 & 0.47 & 0.91 & 0.53 & 0.0090 & $<0.001$ \\
\hline$B$ & 0.12 & 0.32 & 0.51 & 0.93 & 0.54 & 0.0082 & 0.021 \\
\hline$C$ & 0.12 & 0.32 & 0.47 & 0.95 & 0.54 & 0.0056 & 0.017 \\
\hline$D$ & 0.13 & 0.30 & 0.48 & 0.95 & 0.52 & 0.002 & 0.001 \\
\hline$E$ & 0.11 & 0.39 & 0.49 & 0.96 & 0.52 & 0.0046 & 0.014 \\
\hline$F$ & 0.12 & 0.38 & 0.50 & 2.31 & 0.97 & 0.0102 & $<0.001$ \\
\hline$G$ & 0.12 & 0.41 & 0.52 & 2.18 & 0.98 & 0.0142 & 0.024 \\
\hline
\end{tabular}

* Presented at the 81st ISIJ Meeting, April, 1971, in Tokyo. Manuscript received March 6, 1972.

** Central Research Laboratories, Sumitomo Metal Industries, Ltd., Nishinagasu Hondori, Amagasaki 660. 
made. Creep rupture test was carried out mainly at $550^{\circ} \mathrm{C}$, including some other temperatures. Tensile test at room temperature was also done on some specimens. So as to clarify the effect of ferrite grain size on creep strength, steel $E$ was furnace cooled $\left(30^{\circ} \mathrm{C} / \mathrm{hr}\right)$ from various austenitizing temperatures of $900^{\circ}, 1000^{\circ}$, and $1200^{\circ} \mathrm{C}$. Steels $F$ and $G$ were furnace cooled $\left(20^{\circ} \mathrm{C} / \mathrm{hr}\right)$ after heating at $920^{\circ} \mathrm{C}$ for $30 \mathrm{~min}$ and tempered up to $690^{\circ} \mathrm{C} \times 30 \mathrm{hr}$ to study the stability of the detrimental effect of $\mathrm{Al}$ addition.

Using some of the ruptured specimens, microstruc-

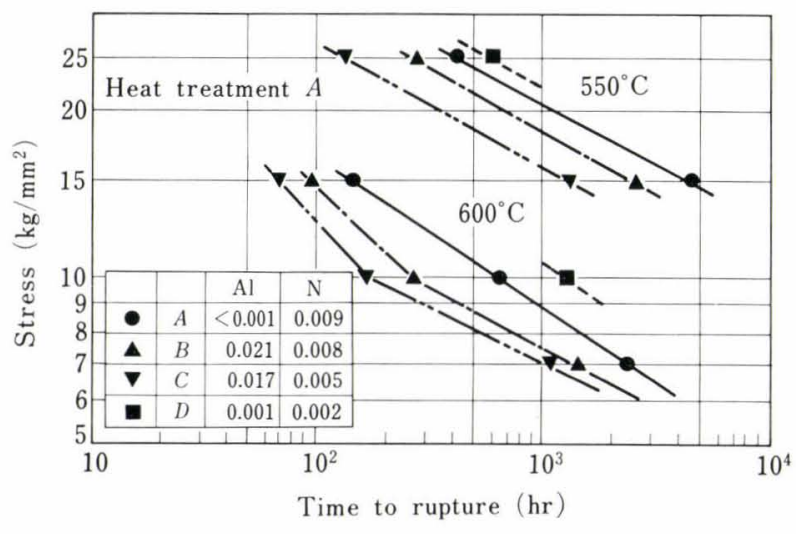

Fig. 1. Stress vs. time to rupture curves at $500^{\circ}$ and $600^{\circ} \mathrm{C}$

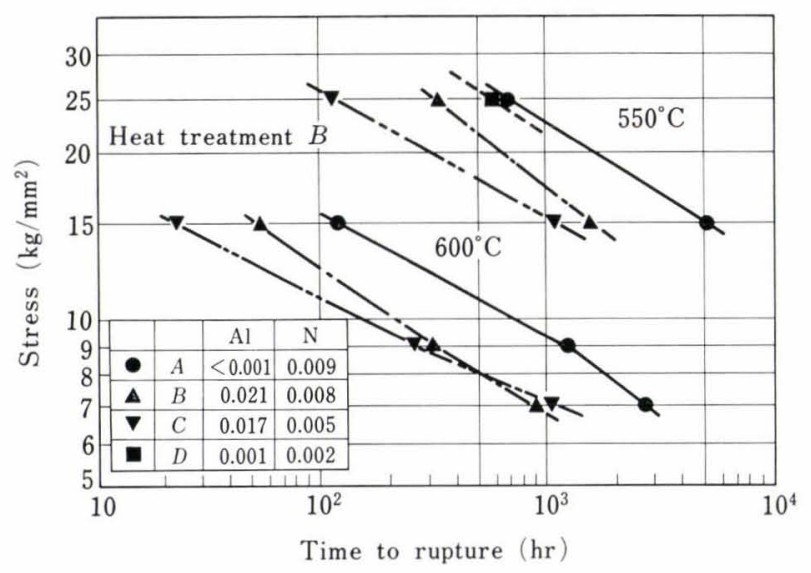

Fig. 2. Stress vs. time to rupture curves at $500^{\circ}$ and $600^{\circ} \mathrm{C}$ tural observation, measurement of grain size, and residue analysis were done.

\section{Experimental Results and Considerations}

\section{Results of Creep Rupture Test}

Results of creep rupture test are shown in Figs. 1 and 2. As shown in these figures, the injurious effect of aluminum addition is obvious. Any particular difference between heat treatments $A$ and $B$, by comparing Figs. 1 and 2, are not seen. As already mentioned, the reason why the two heat treatments were compared was to make clear the supposed possibility of the change of the precipitation behaviour.

Taking both the harmful effect of aluminum on creep strength and the well-known grain refining effect of aluminum (Photo. 1) into account, the relationship between creep rupture time and ferrite grain size was observed. The result is shown in Fig. 3, for both heat treatments $A$ and $B$. Although there is a scattering,

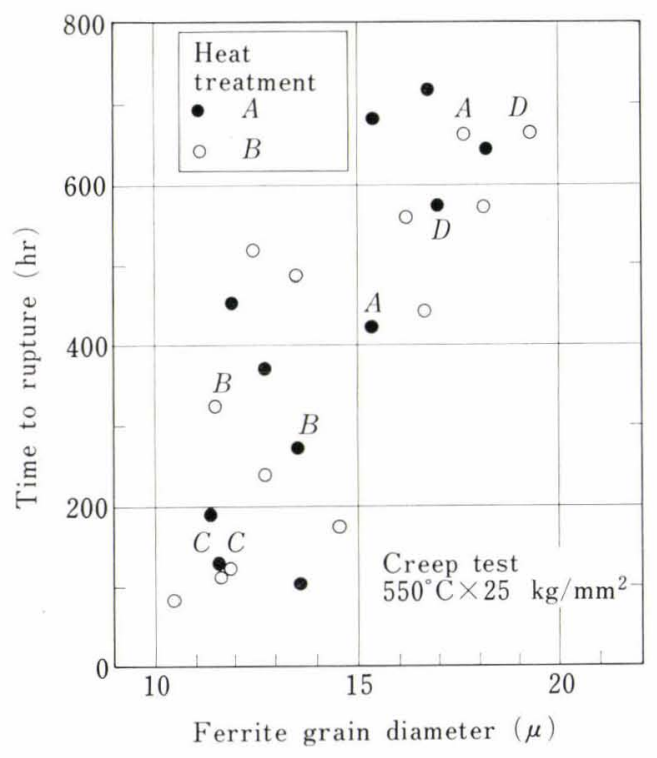

Fig. 3. Relationship between ferrite grain diameter and time for rupture. (This figure includes the unpublished data by Yukitoshi et al.)

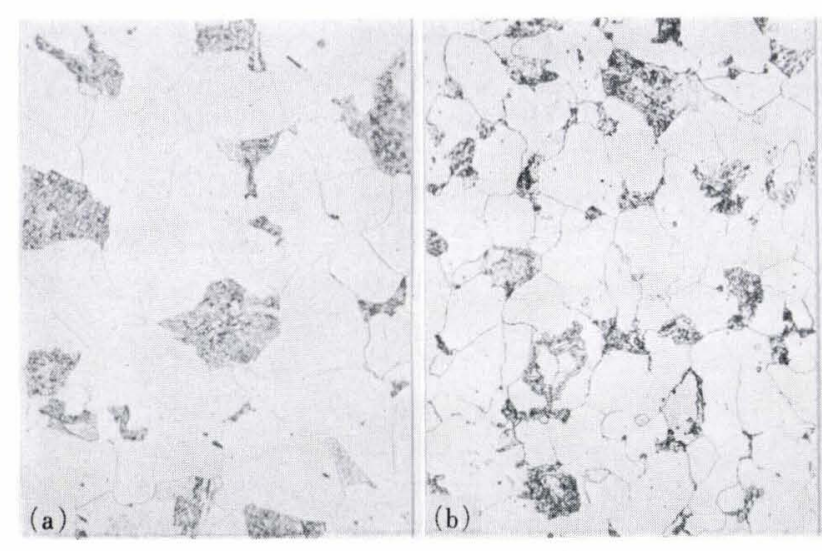

(a) Steel $A: 0.009 \mathrm{~N}-<0.001 \mathrm{Al}$

(b) Steel $B: 0.0082 \mathrm{~N}-0.021 \mathrm{Al}$
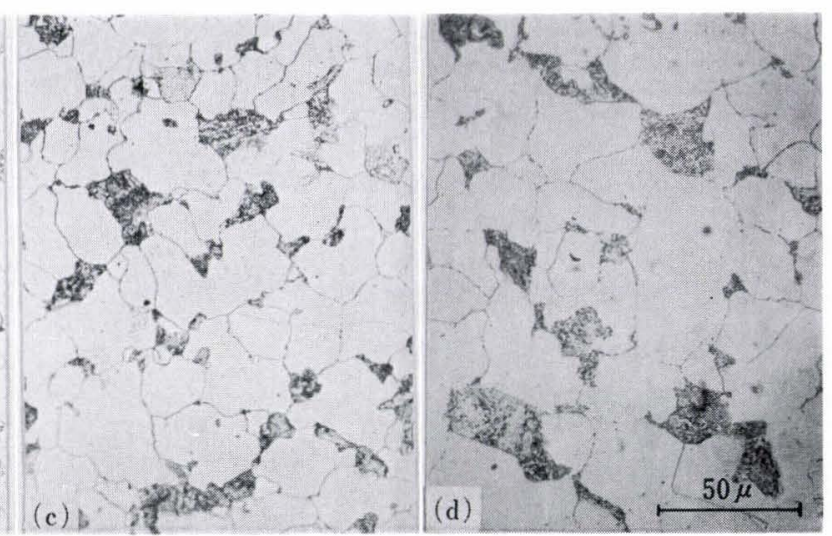

(c) Steel $C: 0.0056 \mathrm{~N}-0.017 \mathrm{Al}$

(d) Steel $D: 0.002 \mathrm{~N}-0.001 \mathrm{Al}$

Photo. 1. Optical microstructure. Heat treatment: $A$ 
a correlation between ferrite grain size and rupture time can be observed.

\section{Results of Residue Analysis}

Active nitrogen in carbon steel plays an important role in raising its creep strength. In low alloy steel, however, slow cooling or tempering around $700^{\circ} \mathrm{C}$ is often carried out, which is supposed to be a condition enough to form nitride. ${ }^{1)}$ In addition to the heat treatment, most low alloy steels contain chromium, which is expected to form CrN. Moreover, the effect of active nitrogen on creep strength may decrease with increasing test temperature. The possibility of strengthening by CrN may be supposed.

As mentioned above, many possibilities are imaginable. Interesting results of residue analysis were obtained for low alloy steels. They are summarized in Table 2. Only a quarter of total nitrogen was fixed as nitride in $1 / 2 \mathrm{Mo}$ steel, whereas in $1 / 2 \mathrm{Cr}-1 / 2 \mathrm{Mo}$ steel one half of total nitrogen was fixed. In $1 \mathrm{Cr}-$ $1 / 2$ Mo steels, because of a higher content of chromium, almost all of nitrogen in the steel was fixed, taking some diversion into account. In $11 / 4 \mathrm{Cr}-1 / 2 \mathrm{Mo}$ steel, similarly, all of nitrogen in the steel was fixed as nitride. From these results, it is clear that nitride forming tendency correlates to the amount of chromium in the steel. This fact indicates that the injurious effect of aluminum on creep strength can not be ascribed to the decrease of active nitrogen, at least in $1 \mathrm{Cr}-1 / 2 \mathrm{Mo}$ steel.

In the above analyses, nitrogen as nitride was measured on air cooled specimens. As for the effect of cooling rate, the residue analyses of nitride on both W.Q. and A.C. specimens of $21 / 4 \mathrm{Cr}-1 \mathrm{Mo}$ steel were done. As is summarized in Table 3, the cooling rate after tempering has little effect on the amount of nitrogen as nitride. As for the possibility of strengthening by $\mathrm{CrN}$, no precise measurement was done. From electron micrographs, however, any distinct difference was not detected as shown in Photo 2. So as to clarify the kind of nitride, the isolation by bromalcohol or chromic acid was done on both silicon

Table 2. Results of residue analysis

\begin{tabular}{|c|c|c|c|c|}
\hline Steel & Mark & Sol. Al & Total N & $\frac{\mathrm{N} \text { as nitride }}{\text { Total } \mathrm{N}}$ \\
\hline \multirow{3}{*}{$1 / 2 \mathrm{Mo}$} & 1 & 0.001 & 0.0078 & 0.19 \\
\hline & 2 & 0.001 & 0.0060 & 0.33 \\
\hline & 3 & 0.001 & 0.0068 & 0.25 \\
\hline $1 / 2 \mathrm{Cr}-1 / 2 \mathrm{Mo}$ & 4 & 0.002 & 0.0076 & 0.54 \\
\hline \multirow{4}{*}{$1 \mathrm{Cr}-1 / 2 \mathrm{Mo}$} & $A$ & $<0.001$ & 0.009 & 0.89 \\
\hline & $B$ & 0.021 & 0.0082 & 1.00 \\
\hline & 5 & 0.002 & 0.0048 & 1.00 \\
\hline & 6 & 0.001 & 0.0032 & 1.00 \\
\hline \multirow{2}{*}{$\begin{array}{l}1 \mathrm{1} / 4 \mathrm{Cr}- \\
1 / 2 \mathrm{Mo}\end{array}$} & 7 & 0.004 & 0.0060 & 0.83 \\
\hline & 8 & 0.005 & 0.0062 & 1.00 \\
\hline
\end{tabular}

Note: Heat treatment: $A$ Extraction: brom-alcohol killed and $\mathrm{Si}-\mathrm{Al}$ killed steels. Results are shown in Fig. 4. It is impossible to avoid carbides in the isolated residues and it takes much time to solve low alloy steel in comparison with carbon steel. In advance, the comparison of extraction solutions was done and brom-alcohol proved to be as usable as iod-alcohol. As brom-alcohol could dissolve steel more rapidly than iod-alcohol, brom-alcohol was used as the extraction

Table 3. Results of residue analysis

\begin{tabular}{|c|c|c|c|}
\hline Steel & & Mark & $\mathrm{N}$ as Nitride \\
\hline \multirow{3}{*}{$21 / 4 \mathrm{Cr}-1 \mathrm{Mo}$} & & $X$ & $0.0093($ wt \%) \\
\hline & & $Y$ & $0.0094(,)$, \\
\hline & & $Z$ & $0.0092(,)$, \\
\hline \multirow[t]{3}{*}{ Note } & $X:$ & $930^{\circ} \mathrm{C} \times 30 \mathrm{~min}$ & $\begin{array}{rr}\text { Total N : } & 0.0096 w t \% \\
\text { Sol.Al : } \quad 0.001 w t \% \\
\text { A.C. }+690^{\circ} \mathrm{C} \times 300 \text { hr W.Q. }\end{array}$ \\
\hline & $Y:$ & " & $+690^{\circ} \mathrm{C} \times 300 \mathrm{hr}$ A.C. \\
\hline & $Z:$ & ", & $+690^{\circ} \mathrm{C} \times 300 \mathrm{hr}$ F.C. \\
\hline
\end{tabular}

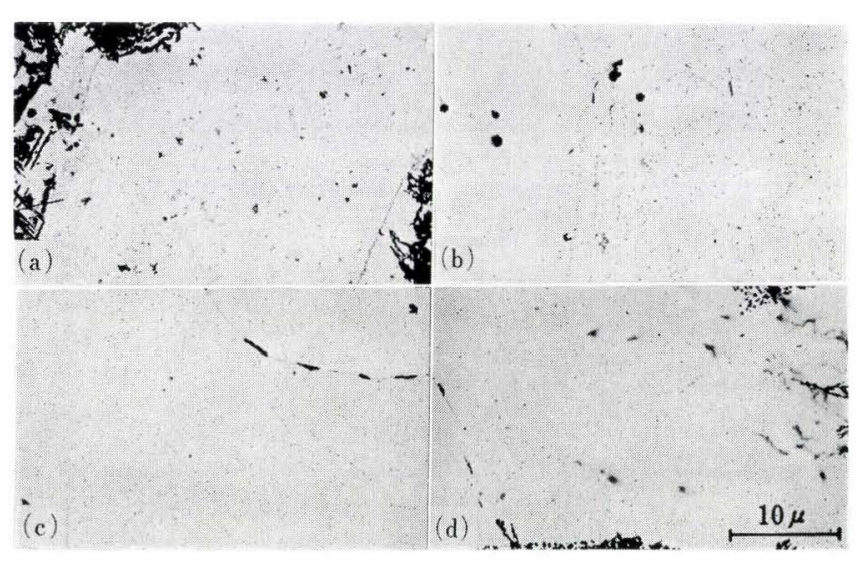
(a) Steel $A: 0.009 \mathrm{~N}-<0.001 \mathrm{Al}$
(b) Steel $B: 0.0082 \mathrm{~N}-0.021 \mathrm{Al}$
(c) Steel $C: 0.0056 \mathrm{~N}-0.017 \mathrm{Al}$
(d) Steel $D: 0.002 \mathrm{~N}-0.001 \mathrm{Al}$

Photo. 2. Electron microstructure. Heat treatment: $A$

\begin{tabular}{|c|c|c|c|c|c|}
\hline & Heat & Extrac. & & $\mathrm{N}$ in residues & $\times 10^{-4}(\mathbf{w t} \%)$ \\
\hline & treatment & tion & 20 & $40 \quad 60$ & $80 \quad 100$ \\
\hline & $1300^{\circ} \mathrm{C} \times 10 \mathrm{~min}$ & $\mathrm{HCl}$ & $\nabla$ & & \\
\hline Steel $A$ & A.C. & $\mathrm{Br}$ & 7 & & \\
\hline$<0.001$ & $1300^{\circ} \mathrm{C} \times 10 \min$ & $\mathrm{HCl}$ & $\Delta$ & 1 & \\
\hline & $\times 5 \mathrm{hr}$ A.C. & $\mathrm{Br}$ & & & \\
\hline $0.0090 \mathrm{~N}$ & $920^{\circ} \mathrm{C} \times 10 \mathrm{~min}$ & $\mathrm{HCl}$ & $\otimes$ & & \\
\hline & A.C. & $\mathrm{Br}$ & & & \\
\hline & $1300^{\circ} \mathrm{C} \times 10 \mathrm{~min}$ & $\mathrm{HCl}$ & 8 & & \\
\hline Steel $B$ & A.C. & $\mathrm{Br}$ & & & \\
\hline $0.021 \mathrm{Al}$ & $1300^{\circ} \mathrm{C} \times 10 \mathrm{~min}$ & $\mathrm{HCl}$ & 直 & & \\
\hline & $\times 5 \mathrm{hr}$ A.C. & $\mathrm{Br}$ & & & \\
\hline $0.0082 \mathrm{~N}$ & $920^{\circ} \mathrm{C} \times 10$ min & $\mathrm{HCl}$ & DV & & \\
\hline & A.C. & $\mathrm{Br}$ & & & \\
\hline
\end{tabular}

Fig. 4. Results of residue analysis 
solution in this experiment. Another extraction solution is an aqueous solution of $20 \% \mathrm{HCl}$, which was reported by $\mathrm{W}$. Koch ${ }^{14)}$ to be able to isolate all of the $\mathrm{CrN}$ in steel. Hence, residues isolated by bromalcohol consist of $\mathrm{AIN}, \mathrm{Si}-\mathrm{Mn}-\mathrm{N}, \mathrm{CrN}$, and carbides, whereas residues isolated by $\mathrm{HCl}$ contain $\mathrm{CrN}$, carbides, and trace amounts of AlN and $\mathrm{Si}-\mathrm{Mn}-\mathrm{N}$. The result of $\mathrm{X}$-ray diffraction analysis in Table 4 shows that $\mathrm{Mo}_{2} \mathrm{C}$ and $\mathrm{CrN}$ are detected in residues isolated by $\mathrm{HCl}$ and, $\mathrm{Mo}_{2} \mathrm{C}, \mathrm{CrN}$, and $\mathrm{Fe}_{3} \mathrm{C}$ are found in residues isolated by brom-alcohol. The diffraction lines of $\mathrm{CrN}$ is stronger in residues isolated by $20 \% \mathrm{HCl}$ than in residues isolated by brom-alcohol. The reason for this is the decrease in the amount of $\mathrm{Fe}_{3} \mathrm{C}$ in the former. As is known from Fig. 4, as most of the nitride in Si-killed steel is $\operatorname{CrN}$ that is insoluble in $20 \% \mathrm{HCl}$, whereas in $\mathrm{Al}$-added steel most of the nitride is AlN that is soluble in $20 \% \mathrm{HCl}$.

\section{On the Effect of Tempering Temperature}

As mentioned already, the detrimental effect of aluminum addition in $1 \mathrm{Cr}-1 / 2 \mathrm{Mo}$ steel is not due to the decrease in the amount of active nitrogen, but is supposed to be caused by some other factor. In order

Table 4. Results of X-ray analysis

\begin{tabular}{|c|c|c|c|c|c|}
\hline Heat treatment & \multicolumn{5}{|c|}{ Extraction $\mathrm{Mo}_{2} \mathrm{C}$ CrN $\mathrm{Fe}_{3} \mathrm{C}$} \\
\hline $1300^{\circ} \mathrm{C} \times 10 \mathrm{~min}$ A.C. & Brom & - & - & 一 & $\begin{array}{l}\text { Halation } \\
\text { only }\end{array}$ \\
\hline $1300^{\circ} \mathrm{C} \times 10 \mathrm{~min}$ A.C. & Brom & W & W & SS & \\
\hline$+700^{\circ} \mathrm{C} \times 5$ hr A.C. & $\mathrm{HCl}$ & $\mathrm{S}$ & $\mathrm{mW}$ & - & \\
\hline
\end{tabular}

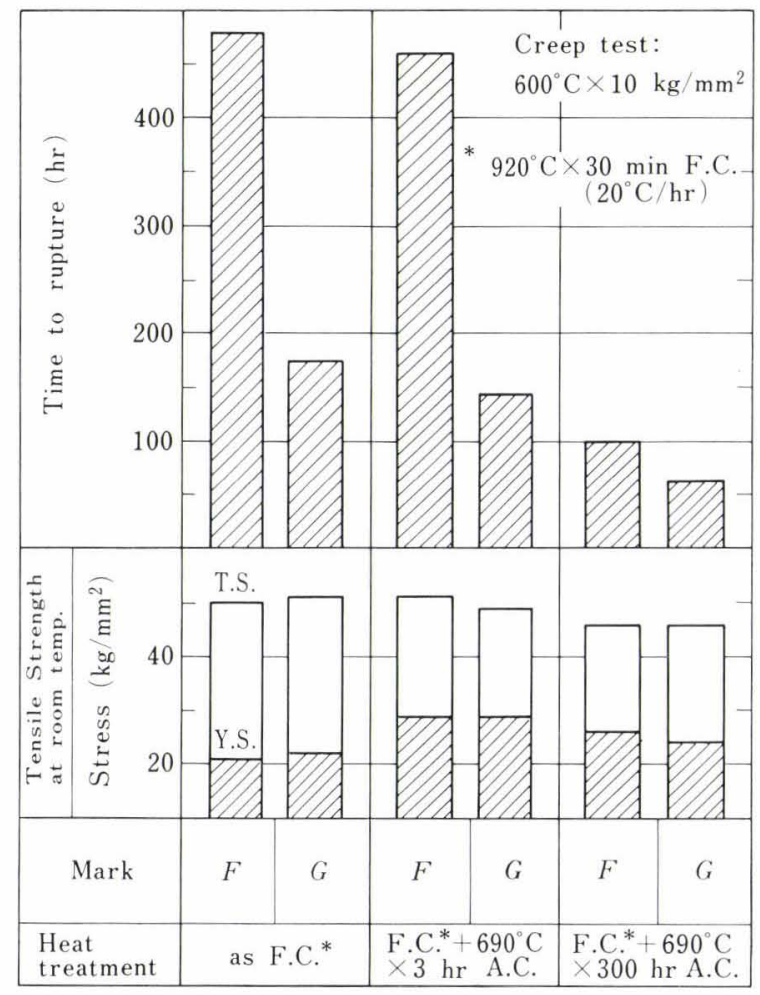

Fig. 5. Effect of aluminum addition on the creep rupture strength of tempered $21 / 4 \mathrm{Cr}-1$ Mo steel to make clear the factor, the effect of tempering temperature on the creep rupture strength of the steel with or without aluminum was sought. Furnace cooling $\left(20^{\circ} \mathrm{C} / \mathrm{hr}\right)$ was done on $21 / 4 \mathrm{Cr}-1 \mathrm{Mo}$ steel. Creep rupture times of $\mathrm{Al}$-trace and $\mathrm{Al}$-added steels were compared. The results are summarized in Fig. 5. Even after such high temperature and long time tempering as $690^{\circ} \mathrm{C} \times 300 \mathrm{hr}$, the detrimental effect of aluminum addition was detected. In these steels, all nitrogen is fixed as nitride because of their high chromium content and slow cooling. This suggests that structural geometrical effects may play main roles in decreasing the creep rupture strength of aluminum added steel.

\section{On the Effect of Ferrite Grain Size}

As for the effect of grain size on creep rate, many reports have been published. ${ }^{10-12)}$ However, the effect is not simple because it is too difficult to analyze creep mechanism and also to isolate the effect of grain size, as was pointed out by C. R. Barrett. ${ }^{13)}$ In the commercial low alloy steels dealt in this report, the formation of two phases (ferrite + pearlite) is inevitable and they contain strong carbide forming elements. So it may be considered that grain size effect includes not only the direct geometrical configurational one but also other ones, such as the change of carbide distribution due to the grain size. Basing on the above consideration, a comparison of creep strengths of steels with different austenitizing temperatures was done. After furnace cooling from austenitizing temperatures of $900^{\circ}, 1000^{\circ}$, and $1200^{\circ} \mathrm{C}$, tensile strength at room temperature and creep rupture

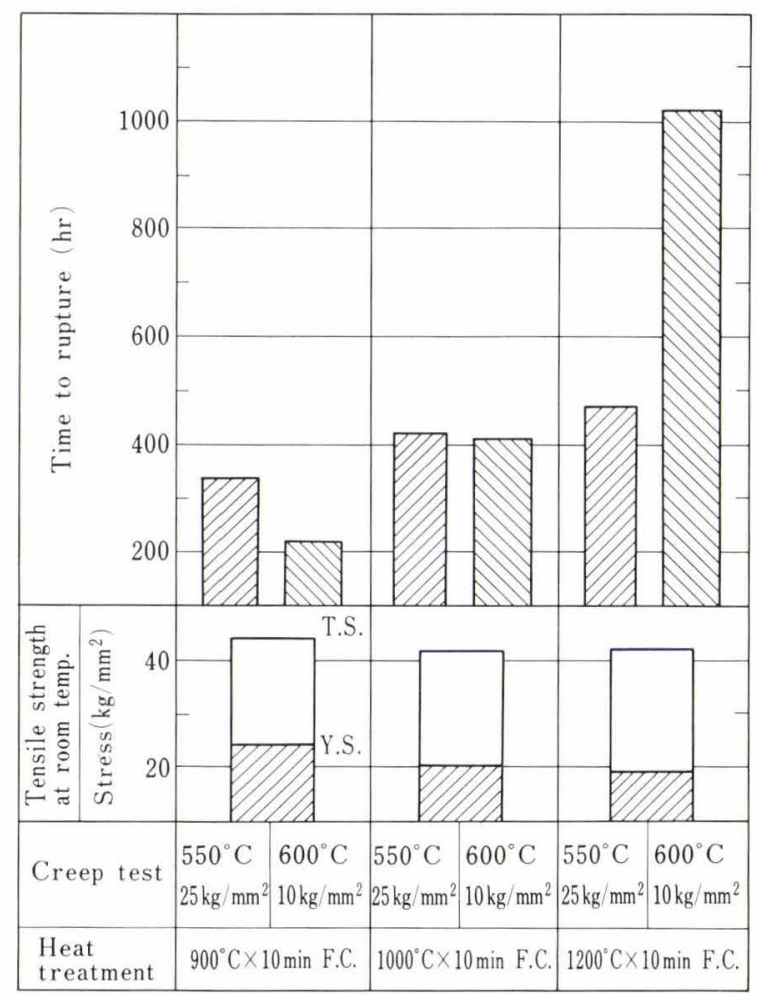

Fig. 6. Results of creep test of furnace cooled $1 \mathrm{Cr}-1 / 2 \mathrm{Mo}$ steel (Al-killed, Steel $E$ ) 


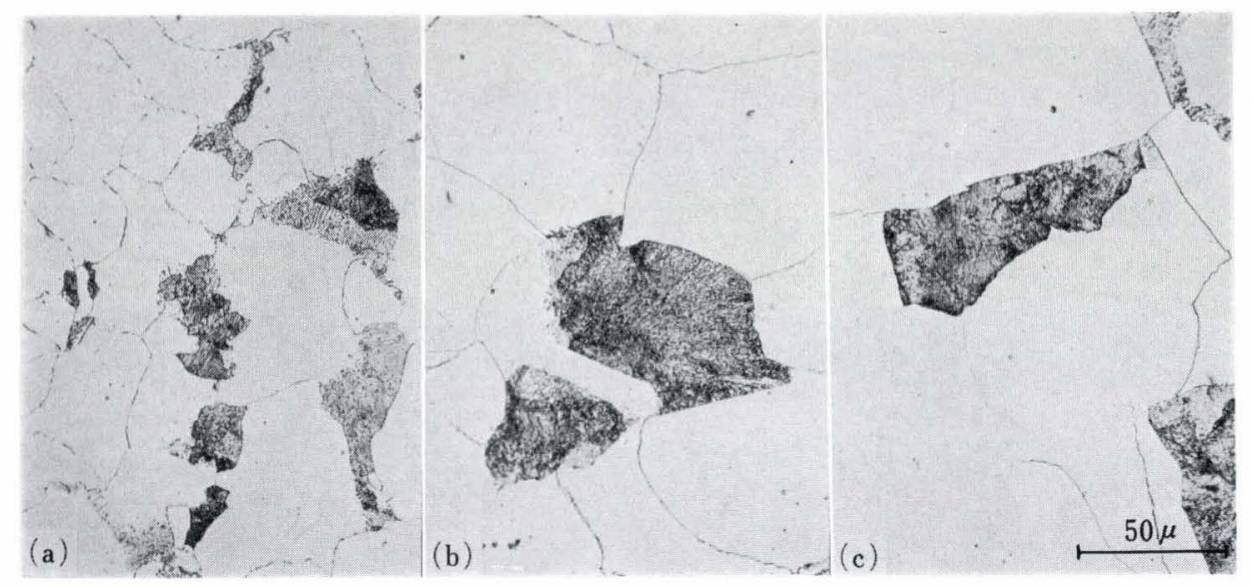

Photo. 3.

Optical microstructure of steel $E$

(a) $900^{\circ} \mathrm{C} \times 10 \mathrm{~min} \mathrm{F.C.}$ $\left(30^{\circ} \mathrm{C} / \mathrm{hr}\right)$

(b) $1000^{\circ} \mathrm{C} \times 10 \mathrm{~min}$ F.C. $\left(30^{\circ} \mathrm{C} / \mathrm{hr}\right)$

(c) $1200^{\circ} \mathrm{C} \times 10 \mathrm{~min}$ F.C. $\left(30^{\circ} \mathrm{C} / \mathrm{hr}\right)$

strength were measured. The results are shown in Fig. 6. As the heat treatments of these specimens differ from heat treatments $A$ or $B$, a direct comparison can not be done. However, among these specimens, it is clear that creep strength increases with increasing austenitizing temperature. As shown in Photo. 3, the increase in austenitizing temperature corresponds to coarser ferrite grain size. Nitride analysis assured that all of the nitrogen in the steel was fixed as nitride.

It is reported in literature that coarse grain steel does not always show small creep rate, and in some cases, optimum grain size exists for creep rate and the effect of grain size often reverses depending on the testing temperature. In order to make clear the effect of creep test temperature, a creep rupture test at various temperatures was done on both $\mathrm{Al}$-trace and $\mathrm{Al}$ added steels for about $1000 \mathrm{hr}$. The results are shown in Fig. 7. Al-trace steel always showed longer creep rupture time than $\mathrm{Al}$-added steel at the temperatures ranging from $500^{\circ}$ to $650^{\circ} \mathrm{C}$.

As already pointed out, the detrimental effect of Al-addition on $\mathrm{Cr}-\mathrm{Mo}$ steel could not be ascribed to the decrease in active nitrogen of steel. Possible factors that may affect creep strength by Al-addition are as follows: (1) aluminum or AlN may affect the distribution of carbides, (2) grain size refining may incur the weakening of creep strength. As mentioned already, it is clear that grain refining surely damages creep strength and that the detrimental effect by Aladdition is stable even after long time tempering at high temperature. These facts are considered to support that the grain refining plays main role for the weakening of creep rupture strength.

\section{Conclusions}

The effect of aluminum and nitrogen on the creep rupture strength of low alloy $\mathrm{Cr}-\mathrm{Mo}$ steels were studied. The results obtained are as follows:

(1) A small amount of aluminum addition caused detrimental effect on creep rupture strength.

(2) The effect of ferrite grain size was studied by varying austenitizing temperature. Specimens with coarse grain showed better creep resistance than those with fine grain size.

(3) Residue analysis clarified that the amount of nitrogen as nitride in as heat treated specimen showed

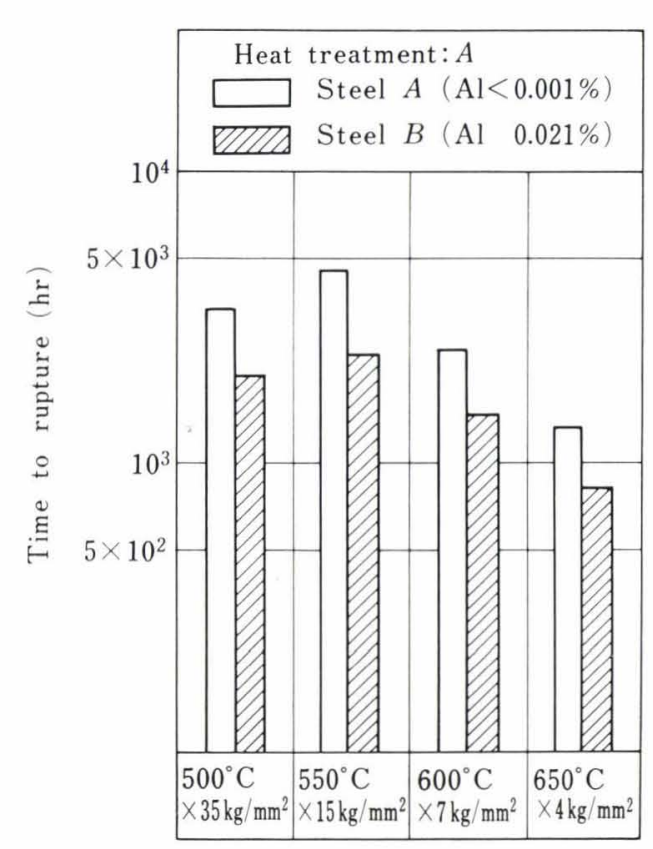

Fig. 7. The effect of aluminum addition on the creep rupture strength at various testing temperatures

an increasing tendency with increasing chromium content. In the case of $1 \mathrm{Cr}-1 / 2 \mathrm{Mo}$ steel, all of the nitrogen in the steel existed as $\mathrm{CrN}$. This means that the detrimental effect of aluminum addition could not be ascribed to the decrease in the amount of active nitrogen.

(4) Grain refining effect of AlN was suggested to play an important role in the detrimental effect of aluminum addition.

From these results, the detrimental effect of aluminum on creep strength was suggested to be ascribed to the grain size dependency, including not only geometrical shape but also the suspected morphological change of precipitates.

\section{REFERENCES}

1) E. Miyoshi and T. Okada: Tetsu-to-Hagané, 53 (1967), 1254.

2) J. Glen: ISI Special Rep., No. 81 (1963), 45.

3) W. E. Bardgett and M. G. Gemmill: JISI, 179 (1955), 211. 
4) S. Terai: The effect of deoxidation condition on the creep strength of carbon and $\mathrm{Cr}$-Mo steels for boiler tube, (1961).

5) S. Terai: Tetsu-to-Hagané, 43 (1957), 136.

6) S. Terai: Tetsu-to-Hagané, 44 (1958), 417.

7) S. Yüki, K. Kajikawa, and K. Yagi: Tetsu-to-Hagané, 51 (1965), 2107.

8) T. Mimino, K. Kinoshita, and Y. Ihara: Report of the 123rd Committee on Heat Resisting Metals and Alloys, Japan Society for the Promotion of Science, 11 (1970), No. $2,215$.
9) H. Nakamura and M. Fukagawa: Zairyo Kagaku, 2 (1965), 30.

10) Y. Imai and T. Murata: Nippon Kinzokugakkai Kaihō, 6 (1967), 585

11) Edited by Nippon Kinzokugakkai: Heat Resisting Alloy (1964), 39.

12) J. Glen: JISI, 179 (1955), 330.

13) C. R. Barrett, J. L. Lytton, and O. O. Sherby: Trans. AIME, 239 (1967), 170. 